Original Article

\title{
Changes in the feeding behavior and habitat use of the desert hedgehog Paraechinus aethiopicus (Ehrenberg 1832, Eulipotyphla: Erinaceidae), in Saudi Arabia
}

\author{
Mudanças no comportamento alimentar e no uso do hábitat do ouriço-do-deserto \\ Paraechinus aethiopicus (Ehrenberg 1832, Eulipotyphla: Erinaceidae), na Arábia Saudita
}

\author{
W. F. Mohameda,b (1) \\ ${ }^{a}$ Ain Shams University, Faculty of Education, Department of Biological and Geological Sciences, Roxy, Cairo, Egypt \\ ${ }^{\mathrm{b}}$ Taibah University, College of Sciences and Arts, Department of Biology, Al-Ula branch, Al Madinah Al Munawwarah, KSA
}

\begin{abstract}
Due to the urbanization and human invasion of the natural environments, great changes have been occurred on the food composition and feeding ecology of several animals especially those are sharing human his habitat in fields, wadis and gardens. The desert hedgehogs Paraechinus aethiopicus populations inhabiting different localities in Saudi Arabia were studied by using stomach contents analysis between February 2015 and October 2019. Precise analysis of stomach contents of 55 hedgehogs showed that the food of $P$. aethiopicus is highly diverse and highly influenced with effect of human on the environment including cooked rice, insects, plant materials, eggshells, worms, garbage and remnants of mammals and birds. Diet composition showed seasonal variations that are apparently associated with changes in the availability of different food items. The present results clearly showed that $P$. aethiopicus is an omnivorous mammal, capable of adapting to a great variety of dietary compositions in the study sites.
\end{abstract}

Keywords: desert hedgehog, Paraechinus aethiopicus, feeding behavior, nutritional ecology, Saudi Arabia.

\begin{abstract}
Resumo
Devido à urbanização e invasão humana dos ambientes naturais, grandes mudanças têm ocorrido na composição alimentar e ecologia alimentar de vários animais, especialmente aqueles que estão compartilhando seu hábitat humano em campos, wadis e jardins. As populações de ouriços-do-deserto Paraechinus aethiopicus que habitam diferentes localidades na Arábia Saudita foram estudadas usando análise de conteúdo estomacal entre fevereiro de 2015 e outubro de 2019. A análise precisa do conteúdo estomacal de 55 ouriços mostrou que a alimentação de $P$. aethiopicus é altamente diversa e altamente influenciada com efeito de humanos no meio ambiente, incluindo arroz cozido, insetos, materiais vegetais, cascas de ovo, vermes, lixo e restos de mamíferos e pássaros. A composição da dieta apresentou variações sazonais que aparentemente estão associadas a mudanças na disponibilidade de diferentes itens alimentares. Os presentes resultados mostraram claramente que $P$. aethiopicus é um mamífero onívoro, capaz de se adaptar a uma grande variedade de composições dietéticas nos locais de estudo.
\end{abstract}

Palavras-chave: porco-espinho-do-deserto, Paraechinus aethiopicus, comportamento alimentar, ecologia nutricional, Arábia Saudita.

\section{Introduction}

The desert hedgehog, Paraechinus aethiopicus, is one of the smallest hedgehogs worldwide, inhabiting hot and temperate regions, river banks, desert wadis and shaded places (Simpson, 1945; Russell, 1949b; Walker, 1964; Hutterer, 2016). It prefers living near water resources to drink water directly; if water is not available, it can get water from food. The hedgehogs have a territory of about $9 \mathrm{~km}$ per night to search food (Pereira et al., 2016). P. aethiopicus hibernates during winter in ground dens with only one entrance, it may occupy dens of other small mammals or in a pile of straw or wood, and becomes active during late spring and summer (Hutterer, 2016). Moreover, the desert hedgehogs can tolerate the modification in their habitats so they are not considered globally threatened. No threats are reported for the species, although some researchers have noted that increasing desertification has led to the decrease of its numbers, and in some areas a lot of them died due to road traffic (Corbet, 1988; Harrison and Bates, 1991; Bates, 2001; Hutterer, 2016).

P. aethiopicusis is distributed across the Sahara, Middle East, Mauritania, Morocco, Algeria, Tunisia, Libya, Egypt, Sudan, Iran, Iraq, Palestine, Jordan, Syria, Kuwait, Oman,

*e-mail: walidfathy72@yahoo.com

Received: October 14, 2020 - Accepted: November 24, 2020 
United Arab Emirates, Yemen, Saudi Arabia and possibly Ethiopia (Prothero, 1920; Symonds, 1999; Mackey, 2002).

P. aethiopicus is slightly larger than the other species of hedgehogs that share its habitat, e.g. Hemiechinus auritus. The body is covered by spines on its back, not found on head. Spines are long and go out in all directions acting as a protective cover to protect the animal from predators; thus, it is extremely difficult to handle the animal. Spines are hollow and have banded pale brown colors with dark tips. The animal can be nested in its strong pointed thorns to protect itself from predators if necessary. The color of the ventral side and feet is a variable combination of brown, black and white. Limbs are dark colored as face. Feet are hairy but soles are bare, with the hind feet helping P. aethiopicus to run fast (Carey and Judge, 2001; MacDonald, 2001; Hutterer, 2016). The muzzle of the hedgehog is black with lighter bands on its forehead. In contrast, tail is short (Carey and Judge, 2001; Macdonald, 2001; Hutterer, 2016). Ears are long to help the animal to radiate the excess heat from its body to the surroundings especially during hot months of summer season. Also, ears help the animal to catch the sounds of the surrounding preys and to escape from them everywhere.

A few data on the changes in the feeding behavior, seasonal changes in foraging behavior and habitat requirements of $P$. aethiopicus are known especially about hedgehogs inhabiting near human settlements. In this context, $P$. aethiopicus feeds on a wide range of food stuffs, but most of its diet is made up of various invertebrates including a wide range of insects especially beetles and caterpillars, and worms, slugs and millipedes. Additionally, the desert hedgehogs also eat eggs, small birds, scorpions, termites and lizards, fallen fruits and carrion (Nader and Al-Safadi, 1993; Ditchkoffet al., 2006; Fekadu and Jorge 2014).

This study aims to elucidate the changes in the feeding behavior of $P$. aethiopicus in different habitats in Saudi Arabia and to discuss the seasonal changes in its nutritional ecology.

\section{Material and Methods}

\subsection{Sampling}

Specimens were collected from five different localities from north and north western locations of Saudi Arabia during February 2015 and October 2019. The five localities were: Sakaka city $\left(29^{\circ} 97^{\prime} \mathrm{N}, 40^{\circ} 21^{\prime} \mathrm{E}\right)$, Al Adare governorate

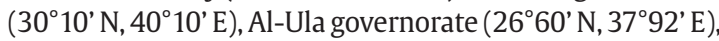
Khaybar governorate $\left(25^{\circ} 41^{\prime} \mathrm{N}, 39^{\circ} 17^{\prime} \mathrm{E}\right)$ and $\mathrm{Al}$ Madinah Al Munawwarah city ( $\left.24^{\circ} 32^{\prime} \mathrm{N}, 3^{\circ} 31^{\prime} \mathrm{E}\right)$. Observations and valuable remarks during the four seasons were recorded thoroughly in each study area via several field trips.

The hedgehogs were captured manually with the aid of dwellers in the five localities, using sedatives. No anesthesia was used. Locality, date of collection, sex, weight and morphological measurements of each specimen were recorded. Special attentions were concentrated to some spots such as rubbish mounds where a lot of hedgehogs were found there during all months of the year due to availability of food resources, and farms where grasses usually attract hedgehogs. A total of 55hedgehogs were hunted, 12 specimens from Sakaka ( 8 males and 4 females), 11 specimens from $\mathrm{Al}$ Adare ( 9 males and 2 females), 14 specimen from Al Ula ( 9 males and 5 females), 8 specimens from Khaybar (4 males and 4 females) and 10 specimens from Al Madinah Al Munawwarah ( 6 females and 4 males).

\subsection{Stomach content analysis}

Live specimens were dissected to get stomach from each hedgehog. Stomachs were kept in 70\% ethanol to keep their contents away from decomposition. All stomach contents were weighed, examined and categorized into main items. Identification of food items of the stomach contents was carried out following the method of Campbell (1973).

Qualitative stomach content analysis was completed in the laboratory by using a stereo microscope, Olympus $\mathrm{SZ}^{\mathrm{TM}},(5 \times$ magnifications). Identification of plant fragments in each stomach was carried out based on the comparison of plant epidermal remnants with a reference collection prepared from plants present at the study areas following the methods described by Storr (1961) and Walid and Basuony (2016). Animal remnants in the stomachs were identified to the species level if it is possible. Identification keys were used for identification of mammals' hair (Harrison and Bates, 1991), bird feathers (Green, 1984 and Jennings, 1989), reptiles (Cox et al., 2012) and plants (Migahid, 1996; Al-Hassan, 2006; El Akkad et al., 2017). Insects were identified to the order level using Walker and Pittaway (1987) as a reference.

Frequency of occurrence for animal and plant food items was calculated according to Sparks and Malechek (1968).

Trophic niche breadth was calculated according to Krebs (2009) to determine the frequency and volume of the various food categories, as follows:

$$
\mathbf{B}=\boldsymbol{\Sigma} \mathbf{1} / \mathbf{P j}^{2}
$$

Where $(\mathrm{Pj})$ is the proportion of records in each food category $(\mathrm{j})$ at $100 \%$. The trophic niche breadth value was calculated seasonally.

\section{Results}

The desert hedgehog P. aethiopicus consumes different food items. Table 1 shows the general composition of its diet, expressed as the number of stomachs containing the item and frequency of occurrences of each item in stomachs (expressed as a percentage of all samples) of all individual food items encountered in the remaining stomach contents.

The results in Table 1 revealed that cooked rice represented the main food item in 34 stomachs (61.81\% frequency of occurrence). P. aethiopicus obtained cooked rice from dumps, human wastes and refuses of parties.

Insects were the second predominant food item in 25 stomachs (45.45\% frequency of occurrence). Insects identified in the stomachs were the American cockroach 
Periplaneta americana, the German cockroach Blatella germanica, the Arabian darkling beetle Pimelia arabica, the domino beetle Anthia duodecimguttata, the praying mantis Mantis religiosa, the Egyptian locust Anacridium aegyptium, the desert locust Schistocerca gregaria and the Tropical field cricket Gryllus bimaculatus.

Different plants were collected from 21 stomachs representing $38.18 \%$ frequency of occurrence. Plant remnants ingested by the specimens are grown in the study sites. The animals may get some cultivated crops such as tomato Solanum lycopersicum, cucumber Cucumis sativus and bell pepper Capsicum annum. Different parts of wild plants were also ingested by the hedgehogs such as Rhazya stricta, Pulicaria incisa and Cucumis prophetarum.

Eggshells represent the fourth food item of hedgehogs in 12 stomachs (21.81\% frequency of occurrence). They were eaten by hedgehogs due to their ability to crash eggshells

Table 1. Occurrence and frequency of occurrence (\%) of food items in the stomach contents of males and females of the desert hedgehog P. aethiopicus collected from the five study sites in Saudi Arabia.

\begin{tabular}{lcc}
\hline Food item & $\begin{array}{c}\text { No. of stomachs } \\
\text { containing item (N = 55) }\end{array}$ & $\begin{array}{c}\text { Frequency of } \\
\text { occurrence } \\
\text { (\%) }\end{array}$ \\
\hline Cooked rice & $34(16 \mathrm{M}+18 \mathrm{~F})$ & $61.81 \%$ \\
Mammals & $1(0 \mathrm{M}+1 \mathrm{~F})$ & $1.81 \%$ \\
Birds & $2(1 \mathrm{M}+1 \mathrm{~F})$ & $3.62 \%$ \\
Insects & $25(16 \mathrm{M}+9 \mathrm{~F})$ & $45.45 \%$ \\
Plants & $21(11 \mathrm{M}+10 \mathrm{~F})$ & $38.18 \%$ \\
Worms & $5(3 \mathrm{M}+2 \mathrm{~F})$ & $9.09 \%$ \\
Garbage & $3(3 \mathrm{M}+0 \mathrm{~F})$ & $5.45 \%$ \\
Eggshells & $12(6 \mathrm{M}+6 \mathrm{~F})$ & $21.81 \%$ \\
\hline
\end{tabular}

by sharp strong teeth. Hedgehogs got them from the human wastes and refuses.

Hedgehogs hunt and eat live worms and segments of annelid worms, which were recorded in 5 stomachs (9.09\% frequency of occurrence). The earth worm Allolobophora caliginosa is the preferable worm.

Little amounts of garbage such as torn papers and pieces of plastic bags were found in 3 male stomachs representing $5.45 \%$ frequency of occurrence.

The lowest frequency of food occurrences was remnants of birds and mammals that were found in 2 (3.62\%) and one stomachs (1.81\%), respectively. Remnants of birds were mostly the domestic chicken Gallus gallus domesticus, while remnants of mammals were mostly dromedary camels Camelus dromedarius and domestic sheep Ovis spp.

Figure 1 shows the comparison between the food items obtained by males and females during the period of the present study.

Table 2 shows a seasonal comparison of stomach contents analysis of $P$. aethiopicus collected from the five study areas between February 2015 and October 2019. It is obvious that a lot of changes in the occurrence of food items took place. Simultaneously, values of the trophic niche breadth showed some seasonal variations, with the minimum value in winter (5.8) and the maximum value in autumn (6.6).

The changes of food items reflect the variations of the available food items in the environment of $P$. aethiopicus collected from the study sites. It is noteworthy that although the calculated values of the niche breadth remain more or less the same; the composition of the food diet shows significant seasonal changes assuming that certain food items are replaced by other items as seasons change. Figure 2 shows the relationship between values of the trophic niche breadth in the four seasons of $P$. aethiopicus during the present work.

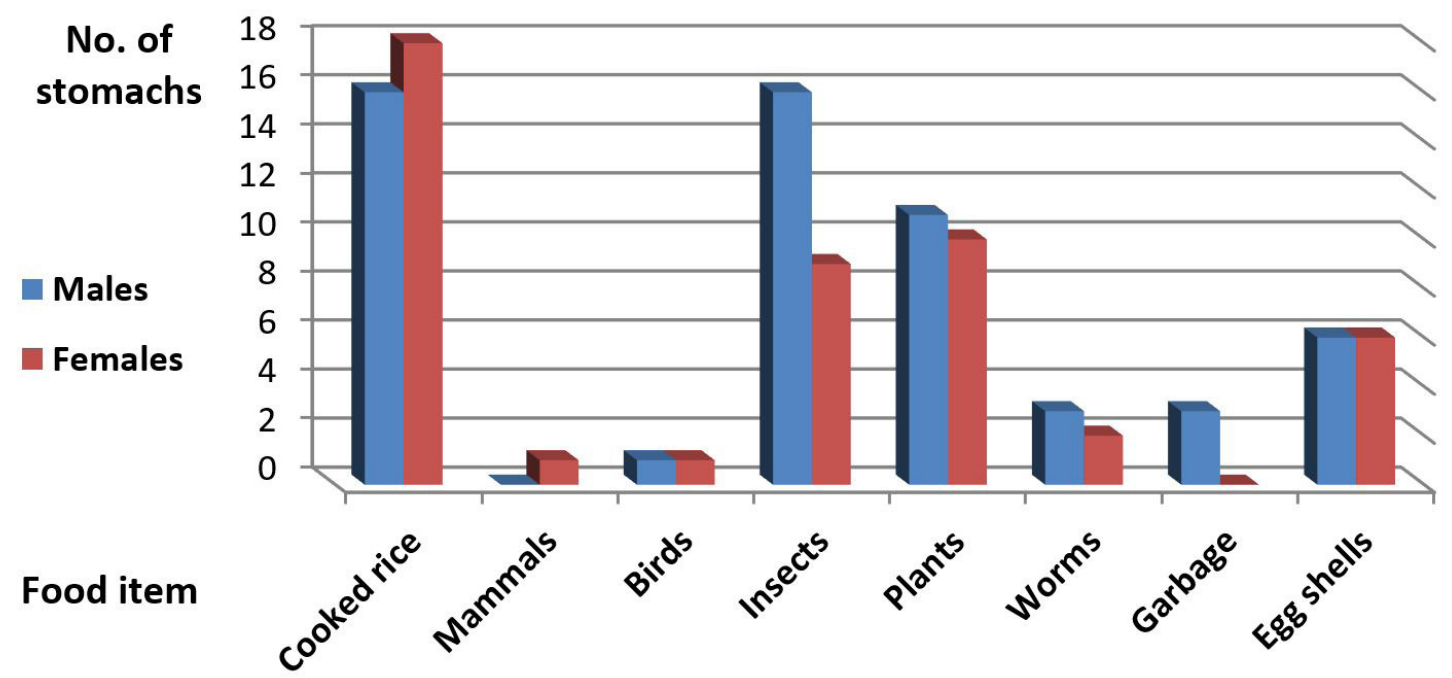

Figure 1. Comparison of food items in the stomach contents of males and females of the desert hedgehogs P. aethiopicus collected from the five study sites in Saudi Arabia. 
Table 2. Seasonal variations in the diet of the desert hedgehog P. aethiopicus collected from the five study sites in Saudi Arabia. (No.): number of occurrence, (F) frequency of occurrence.

\begin{tabular}{|c|c|c|c|c|c|c|c|c|}
\hline \multirow{2}{*}{ Food item } & \multicolumn{2}{|c|}{ Winter $(\mathrm{N}=6)$} & \multicolumn{2}{|c|}{ Spring $(\mathbf{N}=18)$} & \multicolumn{2}{|c|}{ Summer $(N=16)$} & \multicolumn{2}{|c|}{ Autumn (N = 15) } \\
\hline & No. & $\mathbf{F}$ & No. & $\mathbf{F}$ & No. & $\mathbf{F}$ & No. & $\mathbf{F}$ \\
\hline Cooked rice & 4 & 66.6 & 11 & 61.1 & 14 & 87.5 & 10 & 66.6 \\
\hline Mammals & 1 & 16.6 & 6 & 33.3 & 9 & 56.2 & 5 & 33.3 \\
\hline Birds & 0 & 0 & 2 & 11.1 & 4 & 25 & 3 & 20 \\
\hline Insects & 3 & 50 & 8 & 44.4 & 11 & 68.7 & 7 & 46.6 \\
\hline Plants & 2 & 33.3 & 5 & 27.7 & 6 & 37.5 & 5 & 33.3 \\
\hline Worms & 1 & 16.6 & 3 & 16.6 & 4 & 25 & 3 & 20 \\
\hline Garbage & 2 & 33.3 & 3 & 16.6 & 2 & 12.5 & 3 & 20 \\
\hline Eggshells & 3 & 50 & 6 & 33.3 & 6 & 37.5 & 4 & 26.6 \\
\hline Total niche breadth & & 5.8 & & 6.4 & & 6.2 & & 6.6 \\
\hline
\end{tabular}

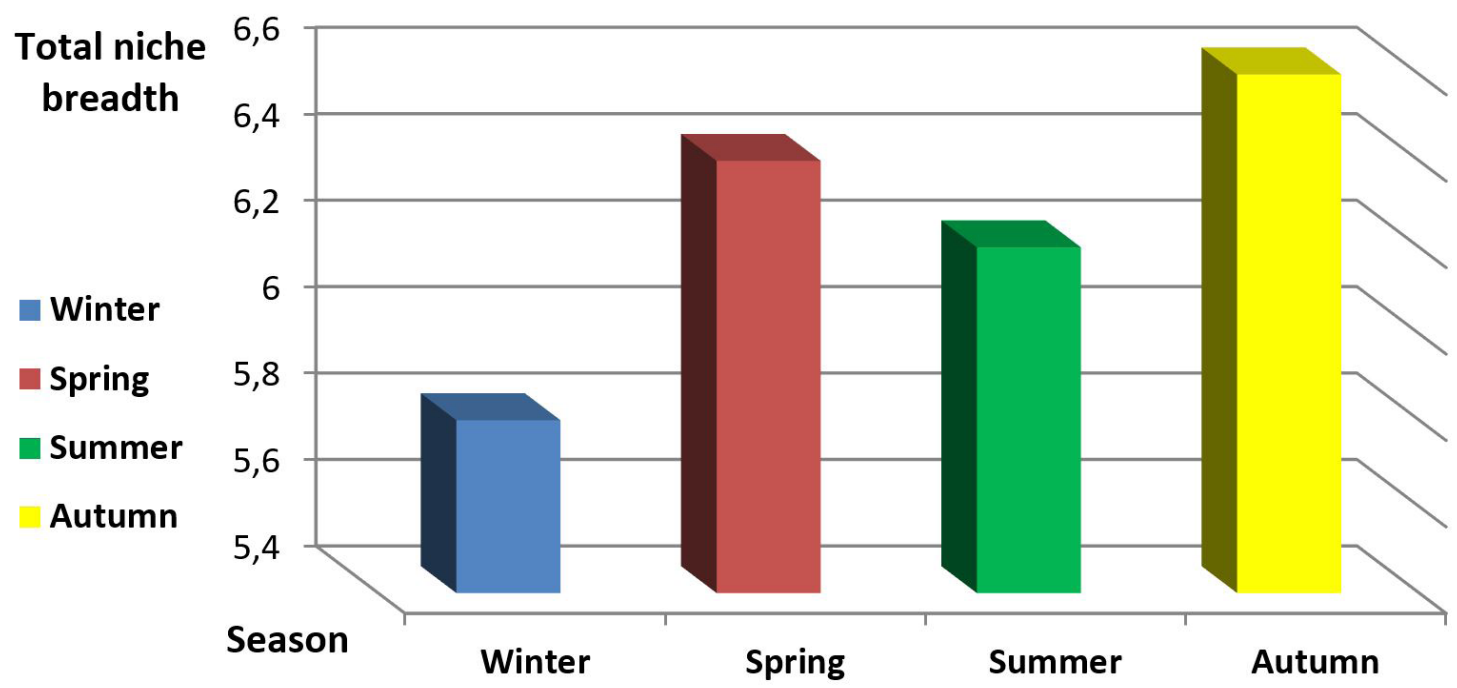

Figure 2. Relationship between values of the trophic niche breadth in the four seasons during period from February 2015 and October 2019 in five study sites in Saudi Arabia.

\section{Discussion}

According to the obtained results, it was found that cooked rice represents the highest food item in the stomachs of both males and females of the hedgehogs (61.81\%). Cooked rice is easily obtained by hedgehogs from dumps, wastes and refuses of wedding parties. Females consume cooked rice more than males; 18 females' stomachs versus 16 males' stomachs were filled with rice. Different insects such as cockroaches, beetles, locusts and crickets have the second rank of the food items in both males and females (45.45\%). Males consumed amounts of insects double the amount in females; 16 males' stomachs versus 9 females' stomachs contained different insects. Different plants were recorded as the third food item in stomachs of males and females (38.18\%). Eggshells were the fourth preferable food item for the hedgehogs (21.81\%).This finding may be due to the ability of these animals to crash and crunch eggshells easily by their sharp teeth.
Optimal foraging theory revealed that an animal chooses its food based on tradeoff between costs and benefits that will give the maximum benefit to it (Krebs et al., 2012). Based on this theory, P. aethiopicus prefers to consume different food items from their habitats and surroundings to get the net benefits from it.

Males of $P$. aethiopicus move about $9 \mathrm{~km}$ per night for foraging (Pereira et al., 2016). Thus, they need sufficient energy to move everywhere. Insects give the animal the suitable energy budget. So males mainly depend on insects as the preferable item of food but due to the appearance of cooked rice they consume it as a quick and easy available source. During foraging, males complete their diets with different food stuffs such as plants and/or eggshells but not considered as main food items for hedgehogs. When hedgehogs fail to get the previous mentioned food items, they start eating worms and odd things such as plastic pieces or torn papers to not feel with hunger. Remnants of meat belonging to 
birds and mammals occupy the last two ranks in the diet of the hedgehogs because they are ingested accidentally with cooked rice lifted by humans from the weddings.

Females are less active than males and they need less energy than males because they have a territory less than $9 \mathrm{~km}$ per night and they are usually wandering near and around their dens (Pereira et al., 2016). This concept explains the reason of why females depend on plants as the next choice food item after getting cooked rice and then insects occupy the third choice for feeding. Female forage the nearest food items found around them, so they eat cooked rice at first. Plant materials are also easy to eat without a great deal of effort, so females ingest plenty of plants to complete their diet. It was found that garbage is not on the list of female's' food because they have different food items that give them the sufficient energy they need. All these food stuffs give females suitable energy but not as high as those required for males.

It was noticed that the trophic niche breadth reached its maximum value in autumn (6.6) and minimum value in winter (5.8). The maximum value in autumn (6.6) followed by spring (6.4)may be due to the great deal of wedding parties at these times and also the great activity of insects in these two seasons, besides that these two seasons represent the active time of the hedgehogs. Variability in trophic niche breadth in the four seasons reflects the great ability of hedgehogs to exploit many food resources in its surrounding areas and to adapt to highly variable dietary circumstances.

\section{Conclusion}

The desert hedgehog $P$. aethiopicus is classified as an insectivore; skull and teeth are modified to perform this function. The present study showed that this hedgehog depends on several types of food items; beside eating insects; during foraging. This finding considers this animal as an omnivorous animal, not a specialist animal. Living as omnivorous is more useful for the ecosystem than being a specialist because omnivorous animals sometimes scavenge deleterious wastes to clean environment from wastes and diseases. Moreover, omnivorous animals eat different types of food so they protect themselves from extinction, P. aethiopicus managed to develop itself to become a useful omnivorous species in its habitats by depending on the available food stuffs especially those dumped by human and changing its feeding behavior and habitat use as a way of adaptation.

\section{References}

AL-HASSAN, H.O., 2006. Wild plants of the Northern Region of the Kingdom of Saudi Arabia, (field guide with photographs). Al Jouf, Kingdom of Saudi Arabia: Ministry of Agriculture, Camel and Research Center. 235 p.

BATES, P., 2001. Arabia's Hedgehogs: Primitive but successful [online]. [viewed 14 October 2020]. Available from: http://www. arabianwildlife.com/archive/vol2.1/hedge.htm

CAMPBELL, P.A., 1973. The feeding behaviour of the hedgehog (Erinaceus europaeus L.) in pasture land in New Zealand.
Proceedings of the New Zealand Ecological Society, vol. 20, pp. $35-40$.

CAREY, J.R. and JUDGE, D.S., 2001. Mammals. In: J.R. CAREY and D.S. JUDGE, eds. Longevity records: life spans of mammals, birds, amphibians, reptiles and fish. Odense University Press. pp. 32-65.

CORBET, G.B., 1988. The family Erinaceidae: A synthesis of its taxonomy, phylogeny, ecology and zoogeography. Mammal Review, vol. 18, no. 3, pp. 117-172. http://dx.doi. org/10.1111/j.1365-2907.1988.tb00082.x.

COX, N.A., MALLON, D., BOWLES, P., ELS, J. and TOGNELLI, M.F., 2012. The conservation status and distribution of reptiles of the Arabian Peninsula. Cambridge, UK: IUCN, 39 p.

DITCHKOFF, S.S., SAALFELD, S.T. and GIBSON, C.J., 2006. Animal behavior in urban ecosystems: modifications due to humaninduced stress. Urban Ecosystems, vol. 9, no. 1, pp. 5-12. http:// dx.doi.org/10.1007/s11252-006-3262-3.

EL AKKAD, S., SOUAYAH, N. and ZALAT, S., 2017). The Common Wild Plants in Al Ula Governorate. Madina, Saudi Arabia: Taibah University Press. 204 p.

FEKADU, S. and JORGE, F., 2014. Tick survey in Ethiopian hedgehogs (Paraechinus aethiopicus) at Thumamah, Saudi Arabia. Wildlife Middle East, vol. 7, no. 1, pp. 25-26.

GREEN, M., 1984. The avifauna of Al Jawf region, north west-Saudi Arabia. Sandgrouse, vol. 6, pp. 48-58.

HARRISON, D.L. and BATES, P.J.J., 1991. The Mammals of Arabia. Sevenoaks: Harrison Zoological Museum, 354 p.

HUTTERER, R., 2016 [viewed 14 October 2020]. Paraechinus aethiopicus. The IUCN Red List of Threatened Species. [online]. Available from: https://www.iucnredlist.org/ species/40606/22326233

JENNINGS, M.C., 1989. The birds of Saudi Arabia; past, present, and future. Wildlife Conservation and Development in Saudi Arabia. In: Proceedings of the 1st Symposium. Riyadh. NCWCD publications, No. 3, pp. 255-262.

KREBS, C.J., 2009. Ecology: The experimental analysis of distribution and abundance. 6th ed. Benjamin Cummings. 816 p.

KREBS, J.R., DAVIES, N.B. and WEST, S.A., 2012. An introduction in behavioural ecology. 4th ed. London: Wiley-Blackwell Scientific Publication. 520 p.

MACDONALD, D.W., 2001. The New Encyclopedia of Mammals. Oxford: Oxford University Press. 930 p.

MACKEY, S., 2002. The Saudis: Inside the Desert Kingdom. New York: W. W. Norton Company. 464 p.

MIGAHID, A.M., 1996. Flora of Saudi Arabia. 4th ed. Riyadh: King Saud University. 939 p.

NADER, I and AL-SAFADI, M., 1993. The Ethiopian Hedgehog Paraechinus aethiopicus (Ehrenberg, 1833) and Brandt's Hedgehog Paraechinus hypomelas (Brandt, 1836) (Mammalia: Insectivora: Erinacidae) from Northern Yemen. In W. BUTTIKER and F. KRUPP, eds. Fauna of Saudi Arabia. Riyadh, Saudi Arabia: National Commission for Wildlife Conservation and Development, pp. 397-400.

PEREIRA, D.L., WALTERS, J., BENNETT, N.C., ALAGAILI, A.N., MOHAMMED, O.B. and KOTZE, S.H., 2016. The Comparative Gastrointestinal Morphology of Jaculus jaculus (Rodentia) and Paraechinus aethiopicus (Erinaceomorpha). Journal of Morphology, vol. 277, no. 5, pp. 671-679. http://dx.doi. org/10.1002/jmor.20526. PMid:26968578.

PROTHERO, G.W., 1920. Arabia. London: H. M. Stationary Office, $146 \mathrm{p}$.

RUSSELL, T., 1949b. Desert fauna. Bulletin Journal of Zoological Society of Egypt, vol. 8, pp. 5-8. 
SIMPSON, G.G., 1945. The principles of classification and a classification of mammals. Bulletin of the American Museum of Natural History, vol. 85, pp. 1-350.

SPARKS, D.R. and MALECHEK, J.C., 1968. Estimating percentage dry weight in diets using a microscope technique. Journal of Range Management, vol. 21, no. 4, pp. 264-265. http://dx.doi. org/10.2307/3895829.

STORR, G.M., 1961. Microscopic analysis of faeces, a technique for ascertaining the diet of herbivorous mammals. Australian Journal of Biological Sciences, vol. 14, no. 1, pp. 157-164. http:// dx.doi.org/10.1071/BI9610157.

SYMONDS, M.R.E., 1999. Life histories of the Insectivora: the role of phylogeny, metabolism and sex differences. Journal of Zoology, vol. 249, no. 3, pp. 315-337. http://dx.doi. org/10.1111/j.1469-7998.1999.tb00768.x.

WALID, F.M. and BASUONY, M.I., 2016. Food composition and feeding ecology of the Arabian Red Fox Vulpes vulpes arabica (Thomas, 1902) in Sakaka, northern Saudi Arabia. Journal of Bioscience and Applied Research, vol. 2, no. 11, pp. 723-728. http://dx.doi. org/10.21608/jbaar.2016.109503.

WALKER, D.H. and PITTAWAY, A.R., 1987. Insects of Eastern Arabia. Macmillan Publishers Ltd., pp. 191.

WALKER, E.P., 1964. Mammals of the world. Walker's Mammals of the World. 6th ed. Ronald M. Nowak. Baltimore: The Johns Hopkins University Press. 784 p. 